\title{
Effects of Seasonal Flooding in Benin City and the need for a Community-Based Adaptation Model in Disaster Management in Nigeria
}

\author{
Butu A. W. ${ }^{1}$, Emeribe C. N. ${ }^{2, *}$ and Ogbomida E. T. ${ }^{2}$ \\ ${ }^{1}$ Department of Geography, Faculty of Arts and Social Sciences, Nigerian Defence Academy, Kaduna, Nigeria \\ ${ }^{2}$ National Centre for Energy and Environment, University of Benin, Benin City, Nigeria \\ Corresponding Author: *emeribe.c@ncee.org.ng
}

\begin{abstract}
The present study aimed to investigate the effects of hydrologically induced environmental problem in Benin City and how communities (considered as non-state actors) can be sustainably integrated/participate in monitoring of environmental change, disaster preparedness, post disaster management mechanisms and influence water resources development/management decisions. The study focused on the seasonal flood events of years 2016 and 2017. The study showed that the impacts of flooding in Benin City ranges from submergence of physical infrastructures, loss of agricultural lands/ farms. Using the Focused Group Discussion and Interview methods, $61.9 \%$ of flood affected persons agreed that their houses were submerged, $80.5 \%$ indicated that their farms, including fish farms, piggery, snail farms, crops and poultry were damaged by floods, 9.6\%, indicated having experienced food stock losses due to floods. Most common diseases/sicknesses experienced were diarrhoea (27\%), malaria (37\%); cough (20\%), while sickness due to snake bite was the least (4\%). Fe and fecal coli form count values were high during seasonal flood event. Most of the hydraulic regulation projects have failed mainly due to poor feasibility study, inadequacy of hydrological data, non-involvement of relevant stakeholder and the complete absence of community based groups during engineering construction works. The study proposed a State-Non-state actors Integrated Model, which will be registered as a Corporate organization to plan and monitor environmental changes relating to climate change, flood and gully erosion disasters and with the active involvement of NEMA, SEMA, LEMA and other related agencies and NGO. Depending on the size of each Local Government Area in Benin, the proposed committee will comprise of 25-50 members. The study recommends capacity building of members in the form of training and re-training in the areas of early warning, preparedness, adaptation, emergency plan, data collection method/analysis, writing of research grants proposals to fund the activities of the committee and monitoring for environmental changes.
\end{abstract}

Keywords: Non-state actors, Flooding, Gully erosion, Community participation, Disaster management

\subsection{Introduction}

The incidences of flood related disaster and gully erosion have increased in Nigeria especially since the $20^{\text {th }}$ century due to industrialization, population expansion and rapid urbanization. In fact, with the exclusion of droughts mostly in the semi-arid part of the country, almost $70 \%$ of damages arising from natural disasters are caused directly or indirectly by floods (Urban and river floods) and gully erosion. The effects of river flooding in recent years are well documented. For example in 2010 flood killed about 1,555 people and displaced 258,000 people and destroyed properties worth millions of naira (Babatunde et al., 2011; Adejuwon and Aina, 2014). The 2012 flood reports had far higher casualties than any other in the history of the country (NEMA, 2012). The Nigerian authorities contained the initial excess run-off through contingency measures, but by the end of September, water reservoirs were overflowing and authorities obliged to open dams to relive pressure in both Nigeria 
and neighboring Cameroon and Niger Republic. By September ending, the floods had affected 134,371 people, displaced 64,473, injured 202 and killed 148. By the end of October, more than 7.7 million people had been affected by the floods, and more than 2.1 million were registered as Internally Displaced People (IDP). In all, about 363 people were reported dead and almost 600,000 houses were damaged or destroyed (NEMA, 2012). Out of Nigeria's 36 states, 32 were affected by the 2012 floods including Edo state where the present study is carried out. The significance of the year 2012 flood disasters in Nigeria lies in the fact that they were unprecedented and unlike past flood event since forty years. Most parts of the States of Nigeria along the rivers Niger and Benue were devastated by these floods, causing huge destruction to the rural and urban infrastructures (farmlands/crops, roads, buildings, drainages, bridges, power lines, etc.) and socio-economic lives of affected areas (Ojigi et al., 2013; Ubachukwu and Emeribe, 2017). Flooding in Nigeria is compounded by the problems of improper solid waste management and unplanned housing. It should be noted that flood in itself is not a disaster, except for the nature of impact, the characteristics of the affected population and functionality of institutional framework to respond to flood hazard. For the purpose of this study, the term flood is taken to mean River, flash floods and flood poundage within an urban setting both of which are caused by excessive rainfall.

Gully erosion on the other hand is the single major process responsible for the loss of billion tonnes of soils worldwide (Matthew and Suleiman, 2012). Murck (1996) estimated the global rate of soil loss through erosion at over 25 billion tonnes per year for both rural and urban environment. In southern Nigeria, gully erosion is responsible for the widespread degradation of arable land, destruction of homes, transportation and communication systems, contamination of water supply, isolation of settlements, migration of communities, etc. In Edo state, Jeje (2005) estimated that 531,417.6 and 329,436.5 tonnes of sediment were removed from gullies in Auchi and Ikpoba slope, Benin City respectively. Apparently, soil erosion has been recognized not only within the rural but also in urban environment (Hughes, 2001; Wall et al., 2003, 2005; Ibitoye, 2006). The effects of gully erosion in Nigeria have been articulated by authors ranging from loss of soil fertility, low crop yields, loss of farm lands, loss of scared sites, damages to infrastructures such as residential buildings, schools, hospitals roads (Hassan and Momoh, 2006; Obiadi et al., 2011; Nwilo et al., 2011; Aliyu et al., 2017) all of which have implications on the socio-economic lives of affected populations. River flooding and gully erosion are climate related and since climate change cannot be stopped, a lot can be done in the area of adaptation.

Nigeria government at national and state levels has made serious efforts at mitigating and management of river flood-related disaster and gully erosion in Nigeria through physical infrastructural interventions. Most recent is the World Bank Nigerian Erosion and Watershed Management Project (NEMAP), ratification of international agreements on disaster management, setting up of Internally Displaced Person's Camps (IDP). The Federal Government has also established the National Emergency Agency (NEMA) to respond to emergency cases in terms of provision of relief and mitigation to victims of disaster such as fire, flooding, storm, and accident, among others. NEMA is structured along: Search and Rescue, Policy and Strategy, Information, Education and Prevention, Administration, Finance and Logistics, Relief and Rehabilitation, Research and Planning.

At the state level there is the State Emergency Management Agency (SEMA) which coordinates Disaster Risk Reduction at the State. At local government level is the Local government Emergency (LEMA).Whereas, SEMA is established at all State levels, LEMA is non- existent in most areas (Ogboi, 2013). While the present NEMA operation structure (Top-Bottom approach) in administering disaster risk reduction policies and regulatory provisions has returned significant benefit to most vulnerable communities, studies have shown that there is more to achieve in terms of disaster risk reduction if complemented with local knowledge ( e.g. Marfai et al., 2008; Anderson and Holcombe, 2013; Rowlands, 2013; Slotterback, 2013). As the moment the top-down approach of disaster management lacks an institutional framework for the involvements of community-based groups in the monitoring of environmental changes (both quantity and quality), pre and post disaster management (taking into accounts socio-economic and cultural factors income level, literacy level, cultural differences and local knowledge/perception of community populations). Although at community levels, NEMA established volunteer schemes from local communities examples are the Grassroots Emergency Volunteers Corps (GEVC) and Emergency Management Vanguard (EMV). 
Unfortunately, the activities of these groups are short-lived and unsustainable as they only engage in advocacy, awareness campaigns during a disaster event as well as provide immediate response to emergency when they occur before the arrival of relevant agencies (Alaci et al., 2017).

Similarly, the present method of IDP camps to cater for the needs of flood affected victims is proven to be highly unsuitable, economic losses (Akujobi, 2013; Alaci et al., 2017), diversion of humanitarian aids and humanitarian crises (Essoh and Abutu, 2018), insecurity, cases of rapes, sexual harassment, forced marriage, infant marriage and outbreak of diseases at these camps (Akuto, 2017). To exacerbate the problem of the present disaster management structure in the country is the dearth of hydrological data for most rivers in Nigeria which is prerequisite for building predictive models. Even where these data exist, they are grossly inadequate or disjointed (Olayinka et al., 2013; Iguniwari, 2018), the implication of which is unsustainable water resources management decisions as well as poor development of models for understanding hydrological response relationship. In the light of the above, it has become very urgent that a study be conducted to evaluate how communities (considered as non-state actors) can be sustainably integrated/participate in monitoring of environmental change, disaster preparedness, post disaster management mechanisms and influence water resources development/management decisions. This underpins the aim of the present study.

\subsection{Materials and Methods}

\subsection{Study area}

Benin City is located on Latitude $06^{\circ} 19^{\prime} \mathrm{E}$ to $6^{\circ} 21^{\prime} \mathrm{E}$ and Longitude $5^{\circ} 34^{\prime} \mathrm{E}$ to $5^{\circ} 44^{\prime} \mathrm{E}$ with an average elevation of $77.8 \mathrm{~m}$ above sea level. Benin City is a pre-colonial city, the capital of defunct MidWestern Region, Bendel State and the present day Edo State. The City consists mainly of three local government areas Oredo, Egor and Ikpoba Okha Local Government Areas; it also consists partly of Ovia Northeast and Uhunmwonde Local Government Areas (Figure 1). The land area of the three main local government areas is as follows: Oredo, $249 \mathrm{~km}^{2}$; Egor, $93 \mathrm{~km}^{2}$ and Ikpoba Okha, $862 \mathrm{~km}^{2}$. The total land area of all the three local government areas is $1,204 \mathrm{~km}^{2}$. According to Google Earth, the total land area of the continuous urbanized Benin City in 2016 is $531 \mathrm{sq} \mathrm{km}$.

Socio-economic activities include commerce, agriculture (farming/fishing), industry, with the oil industrial sub-sector providing the major income for the economy. Available data shows that Edo State is the $25^{\text {th }}$ most populated state in Nigeria with a population of 3,218,332 (NPC, 2006). The 2006 census, which is the most recent, recorded the population of the three main local government areas (Oredo, Egor and Ikpoba Okha) which make up Benin City as 1,085,676 (NPC, 2006). For the purpose of this research, this population is projected from 2006 to be 1,433,620 in 2016.

Benin City occupies a lowland plain in the south and rises slowly to the Esan Plateau towards the north. This region is endowed with fertile soil. The city is underlain by sedimentary formation of the Miocene-pleistocene age often referred to as the Benin Formation. The Benin Formation comprise of mainly consolidated sand and sandy clays covering the whole of the Niger Delta. The topography is predominantly uniform, comprising of a gently undulating surface area rising from about $505 \mathrm{~m}$ in the south-eastern parts to about $215 \mathrm{~m}$ in the northern parts giving a mean elevation of about $83 \mathrm{~m}$ above sea level.

The City is located in the humid tropical rain forest belt of Nigeria with a mean annual rainfall ranging from $2050 \mathrm{~mm}$ to $2161 \mathrm{~mm}$. Temperature values in the area are usually on the high side throughout the year with a minimum annual temperature of $21.90{ }^{\circ} \mathrm{C}$ and a mean annual maximum temperature of $25.10^{\circ} \mathrm{C}$. The vegetation of the area is rain forest, however the original vegetation has been undergoing modifications due to urban expansions, mining and industrial activities. This influx of human activities in the region has impacted on the Benin City environment resulting in series of ecological problems such as flooding and erosion as is been experienced in the city year-in and yearout.

The study adopted both secondary and primary data sources. Secondary data include, archival review of literatures, including government gazette, online and offline articles, newspapers and periodicals. 
Primary data were through the administration of structured questionnaires, Focused Group Discussion (FGD) and utilization of oral interviews in each sampled quarter to evaluate the impacts of flooding in Benin City. Target populations are household heads, religious leaders, youth leaders, market women, community heads.

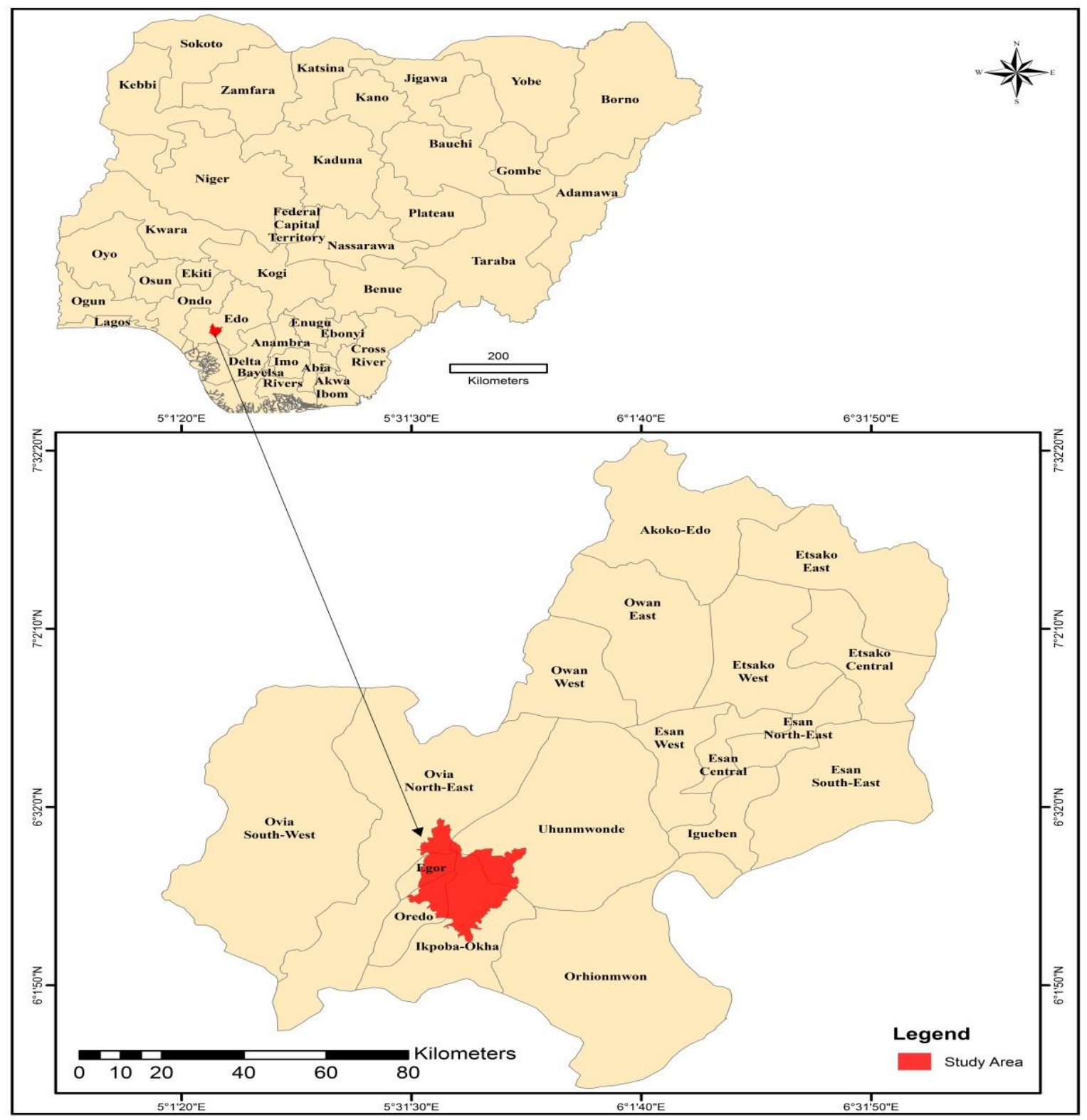

Figure 1: Benin City showing the study area

Source: Modified from Edo State Ministry of Lands and Survey (2014)

Interviews were conducted with stakeholders from the national and state disaster management agencies, water resources development offices of the Federal Water resources and non-governmental Organizations, NGOs. The questions covered existing pre and post disaster responses approaches at community level. Purposive sampling method was adopted in the study to generate information from householders on the impacts of flood disaster and gully erosion. Field surveys/research was used to verify and complement information gathered from literature review. The field surveys covered all relevant elements of the ecological, water sampling and socio-economic environment. Specifically, the following thematic socio-economic indicators were examined in the questionnaire:

- Gender

- Age Distribution

- Marital Status

- Level of Education

- Nature of trade/occupation of APs

- Impacts of flood/gully erosion 
For the purpose of collecting data on the above thematic socio-economic indicators, the study area was divided into five (5) quarters. These five quarters were purposively chosen due the area's history of seasonal floods and impacts. A total of 500 questionnaires were randomly administered during the focused group discussion platforms, 100 questionnaires per sample location (Table 1). Since the study adopted Focused group discussion platform as primary method of data generation, all the questionnaire were answered as the FGD allowed for formal meetings with victims of seasonal floods.

Table 1: Questionnaire administered per quarter

\begin{tabular}{|l|l|l|l|l|}
\hline Street Name & $\begin{array}{l}\text { Number of } \\
\text { Questionnaire }\end{array}$ & $\%$ & Valid \% & Cumulative \\
\hline Upper Mission/Lawani & 100 & 20 & 20 & 20 \\
\hline Imuetinyan Avenue & 100 & 20 & 20 & 40 \\
\hline $\begin{array}{l}\text { Ekosodin/University of Benin } \\
\text { quarters }\end{array}$ & 100 & 20 & 20 & 60 \\
\hline Ogbeson quarter/ Ikpoba Hill & 100 & 20 & 20 & 80 \\
\hline $\begin{array}{l}\text { Osunde Road, East of Murtala } \\
\text { Mohammed Way }\end{array}$ & 100 & 20 & 20 & 100 \\
\hline Total & 500 & 100 & 100 & \\
\hline
\end{tabular}

\subsection{Water quality analysis of Ikpoba River}

Water quality of Ikpoba River was investigated to determine the impacts of seasonal floods on its water quality. Water samples were collected during the flood event. Parameters considered in the study include $\mathrm{pH}, \mathrm{DO}(\mathrm{mg} / \mathrm{l})$, TSS (mg/l), TDS (mg/l), Turbidity (NTU), Chloride (mg/l), Sulphate (mg/l), Nitrate (mg/l), Phosphate (mg/l), Sodium (mg/l), Fe (mg/l), Cu (mg/l), Mn (mg/l), Cd (mg/l), $\mathrm{Pb}(\mathrm{mg} / \mathrm{l}), \mathrm{Zn}(\mathrm{mg} / \mathrm{l}), \mathrm{Cr}(\mathrm{mg} / \mathrm{l}), \mathrm{Ni}(\mathrm{mg} / \mathrm{l})$. Samples were taken from several designated points of the river: upstream (control point) and 2 points downstream. The upstream sampling was done at Sakponba Road, while downstream points sampling was done at Ikpoba Hill axis. In each site, sampling was done at points or near points of abstraction i.e. where the community comes to draw water. This is consistent with a well-known criterion for selecting points for sampling (Hunt et al., 1986). The polyethylene wide-mouth bottles with a firm cover were used for sampling water from streams. During sampling, the bottle was opened at the desired depth of sampling and when the sampler/bottle is full, it was covered firmly before bringing it out of the water. The composite sample was then transferred into two sample containers; 2 polyethylene bottle for physical and chemical analysis and a $100 \mathrm{ml}$ sterilised glass bottle for microbiological analysis in the laboratory. These bottles were pre-cleaned with a detergent and $1 \mathrm{M}$ hydrochloric acid, acetone, and hexane (pesticide grade) and rinsed with water three times, then filled with $500 \mathrm{ml}$ of the sample water and capped. Two (2) $\mathrm{ml}$ of $\mathrm{HCl}$ was added to the water samples collected to prevent microbial activity. Sterilization of the bottle for microbiological was done by an electric oven or by boiling in the absent of electricity. Sampling was carried out between July-October, 2017 (within the period of flood event).

\subsection{Results and Discussion}

The impact of flooding in Benin City ranges from submergence of physical infrastructures, loss of agricultural lands/farms. Using the FGD method, on the average $61.9 \%$ of flood affected persons from the five quarters agreed that their houses were submerged during seasonal flooding, leading to property damages, $80.5 \%$ indicated that their farms (fish farms, crops, piggery and snail farms) were damaged by floods, $9.6 \%$ also indicated having experienced food stock losses due to floods. Most of the sampled quarters are characterized by traditional Courtyard House-Types (Impluvium Design); these include the palace and family compound house-types. Thus both modern water closet and pit latrine are the two major types of sanitary facility in these areas. The study shows that during previous seasonal flood events, $75.4 \%$ indicated that their sanitary facility was unaffected. This has a lot of implications for microbial quality of Ikpoba River which is the receiving River. Flood in the Benin City follows rainfall pattern, September and October is usually the peak of rainfall and this corresponds to flood peak. Usually, submerged houses and farmlands can last into October except when there are interventions. There are also reported cases of disruption of school activities arising from damages to class room blocks, offices, laboratories and even general absence of children from school due to fear of another flood event. Of all the interviewed respondents, an average of $77.1 \%$ 
indicated having at least one member of their household getting sick during each flood event. From FGD, an average of $27 \%$ of the household were affected by diarrhea during flood events, Malaria (37\%), Cough (20\%), Measles (13\%) and Snakebite (4\%) (Table 2). The spread of these diseases may be attributed to increased contamination as a result of diffuse pollution during flooding events. Open dump solid waste disposal method is common in Benin City. The fact that cases of diarrhea and malaria were on the increase due to seasonal flood in Benin City, confirms a similar observation by UNICEF that cases of diarrhea, cholera and malaria increased during the 2012 floods in Nigeria (UNICEF, 2014). Similarly, UNICEF (2014) also found that floods cause environmental pollution through contamination of water; disrupt livelihoods and loss of social network with 21 million people displaced. Plates 1-4, illustrate some of the effects of seasonal flood on physical infrastructures in Benin City.

Table 2: Diseases/Sicknesses experienced by household members during the floods in Benin City

\begin{tabular}{|l|l|l|}
\hline $\begin{array}{l}\text { Diseases experienced by household members during } \\
\text { seasonal flood events }\end{array}$ & No. of response & Valid Percent \\
\hline Diarrhoea & 37 & 27 \\
\hline Malaria & 50 & 37 \\
\hline Cough & 27 & 20 \\
\hline Measles & 18 & 13 \\
\hline Snake bite Total & 5 & 4 \\
\hline \multicolumn{1}{|l|}{} & 137 & 100 \\
\hline
\end{tabular}

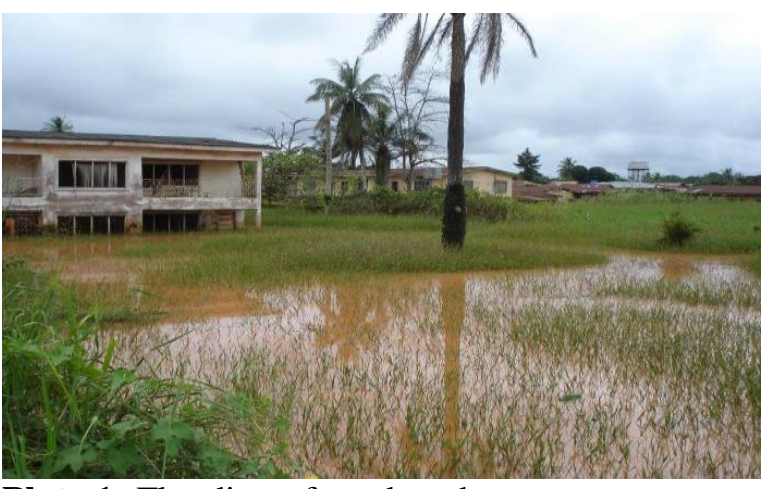

Plate 1: Flooding of teachers house area on Siluko Road, Benin City

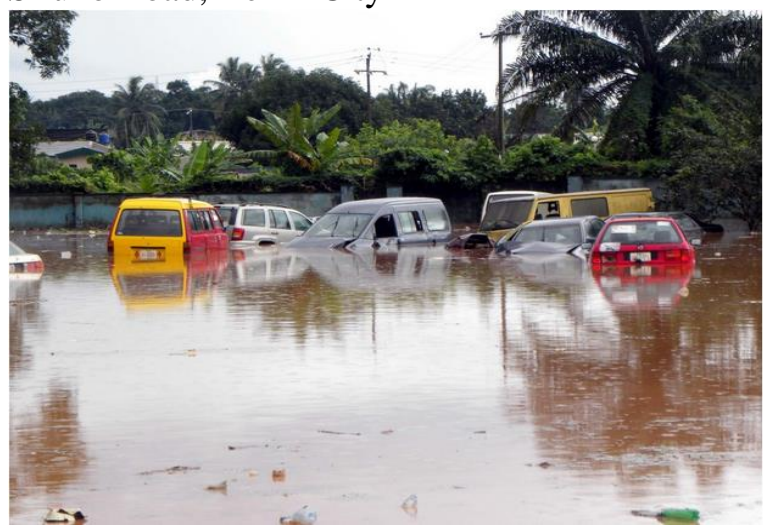

Plate 3: Flooding of Ugbowo/Oluku quarters, Benin City

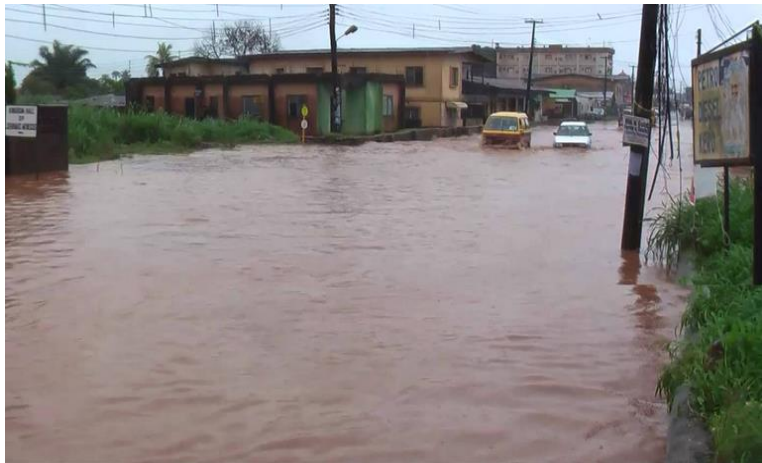

Plate 2: Flooding of Textile Mill Road, Benin City

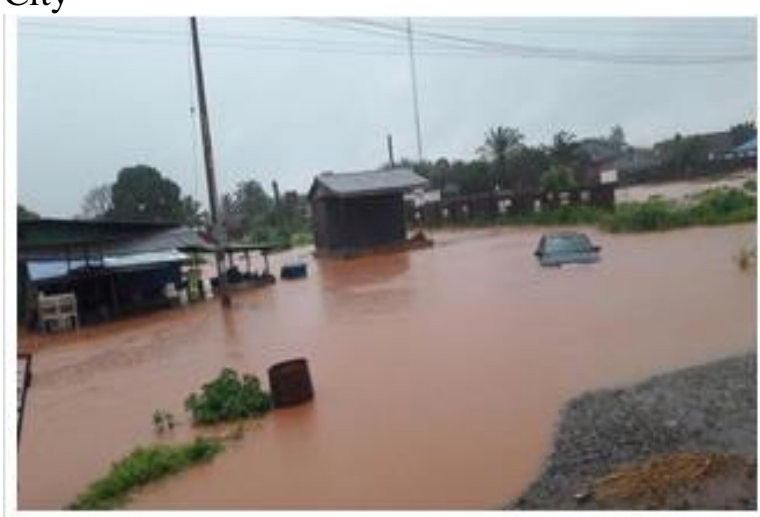

Plate 4: Flooding of Ugbowo/Oluku quarters, Benin City

These wastes which are usually a commingle of organic and inorganic materials are washed down to the Ikpoba river, which is an important source of water for domestic uses and washing bathing as well as source of water supply to the urban water scheme.

Result of the water quality of Ikpoba River, Benin City is presented in Table 3. It should be noted that Ikpoba River is a receptor of most overland flows from Benin metropolis. It can be seen that turbidity, Fe and fecal coli form count values were high during flood event. This is expected due to the impacts of diffuse pollution from urban activities. The fact that other pollution indicators are within range may be attributed to the effect of dilution from rainfall. 
The continuous flooding and resultant erosion in Benin City has ravaged the community around these gullies over the years causing its inhabitants to either vacate their damaged homes or permanently relocate away from the gully area. This in turn has created a state of social isolation for the communities located around the gully sites. The agricultural activity within this region has reduced drastically and farm produce are left to rot during the wet season as a result of inaccessibility to farm lands.

Table 3: Water quality of Ikpoba River, Benin City (data collected in July-October, 2017) during flood event

\begin{tabular}{|l|l|l|l|l|l|}
\hline \multirow{2}{*}{ Parameter } & \multicolumn{3}{|c|}{ Station } & Mean & \multirow{2}{*}{ WHO MPL } \\
\cline { 2 - 4 } & UPS1 & DS1 & DS2 & & \\
\hline $\mathrm{pH}$ & 6.7 & 6.33 & 6.3 & 6.44 & $6.5-8.5$ \\
\hline $\mathrm{DO}(\mathrm{mg} / \mathrm{l})$ & 7.9 & 13 & 3.8 & 8.23 & 6.5 \\
\hline TSS (mg/l) & 12.1 & 107 & 198.7 & 105.93 & 20 \\
\hline TDS (mg/l) & 7.9 & 13 & 11.3 & 10.73 & 500 \\
\hline Turbidity (NTU) & 10 & 19 & 18 & 15.67 & 5.0 \\
\hline Chloride (mg/l) & 1 & 5 & 13 & 6.33 & 250 \\
\hline Sulphate (mg/l) & 0 & 7 & 11 & 6 & 250 \\
\hline Nitrate (mg/l) & 0.003 & 0.024 & 0.03 & 0.019 & 10 \\
\hline Phosphate (mg/l) & 0.21 & 0.53 & 1.15 & 0.63 & 5.0 \\
\hline Sodium (mg/l) & 0.47 & 1.41 & 0.82 & 0.9 & 200 \\
\hline Faecal coliform (cfu/100ml) & 110 & 120 & 140 & 277 & 0 \\
\hline Heavy metals concentrations of Ikpoba River & & & \\
\hline Fe (mg/l) & 0.478 & 1.329 & 1.01 & 0.939 & 0.3 \\
\hline Cu (mg/l) & 0.033 & 0.11 & 0.036 & 0.05967 & 2.0 \\
\hline Mn (mg/l) & 0.023 & 0.044 & 0.034 & 0.03367 & 0.5 \\
\hline Cd (mg/l) & 0.797 & 0.31 & 0.003 & 0.37 & 0.003 \\
\hline Pb (mg/l) & 0.032 & 0.33 & 0.005 & 0.12233 & 0.01 \\
\hline Zn (mg/l) & 0.026 & 0.02 & 0.005 & 0.017 & 3.0 \\
\hline Cr (mg/l) & 0.139 & 0.02 & 0.01 & 0.05633 & 0.05 \\
\hline Ni (mg/l) & 0.204 & 0.34 & 0.025 & 0.18967 & 10 \\
\hline
\end{tabular}

The continuous flooding and resultant erosion in Benin City has ravaged the community around these gullies over the years causing its inhabitants to either vacate their damaged homes or permanently relocate away from the gully area. Generally, most gullies begin as a rill and the erosion progresses downwards by cutting near vertical walls in the partially cemented lateritic soils and/or formations which is typical of the case in Benin City. One rainy season is sufficient to initiate a severe gully and once initiated, the gullies are difficult to control or stop. When the gully reaches the unconsolidated, loose, sand formation (Coastal Plain Sands or Benin Formation), the erosion process accelerates by lateral undercutting resulting in massive slumping (mainly rotational and block slumping) (Plates 5$10)$.

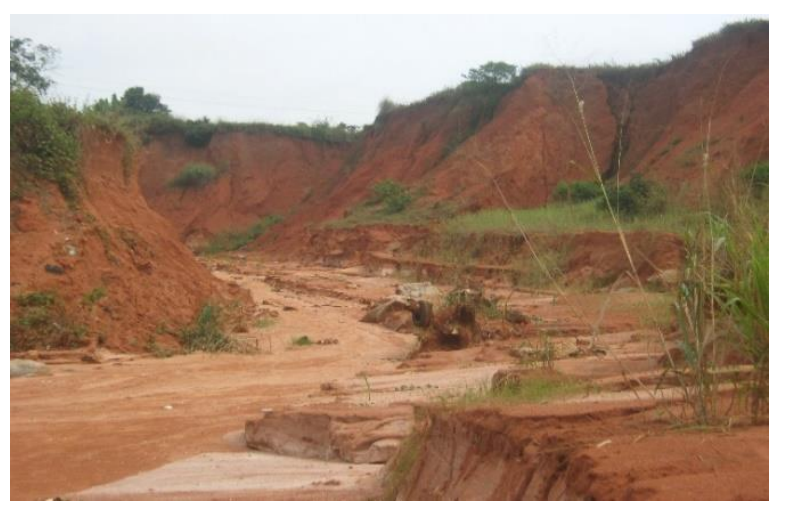

Plate 5: Queen Ede erosion site, Benin City, $2 \mathrm{~km}$ long with an average width of about $70 \mathrm{~m}$

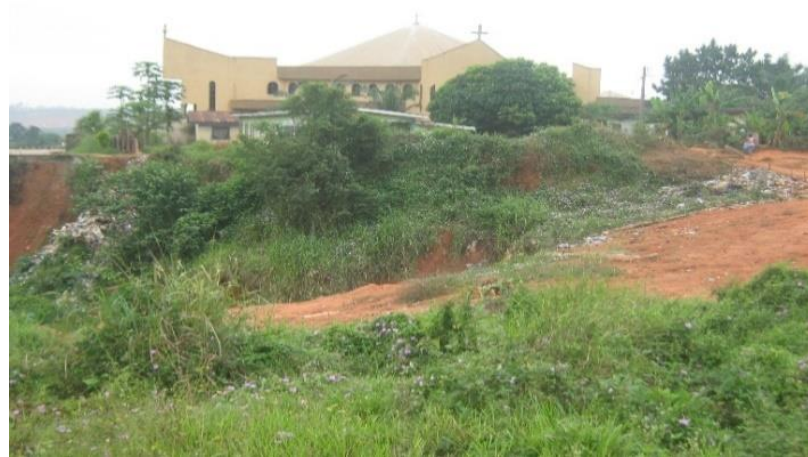

Plate 6: St. Thomas of Aquinas Catholic Church is being threatened by Queen Ede erosion site, Benin City 


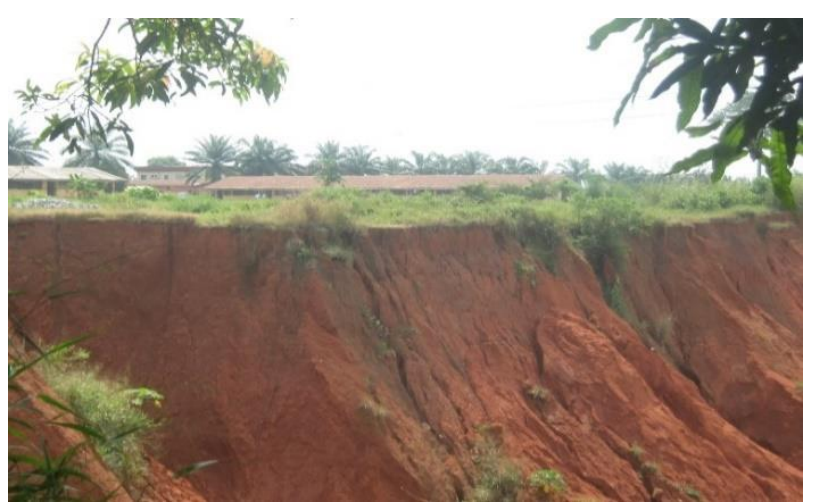

Plate 7: Queen Ede Secondary School being threatened by Queen Ede erosion

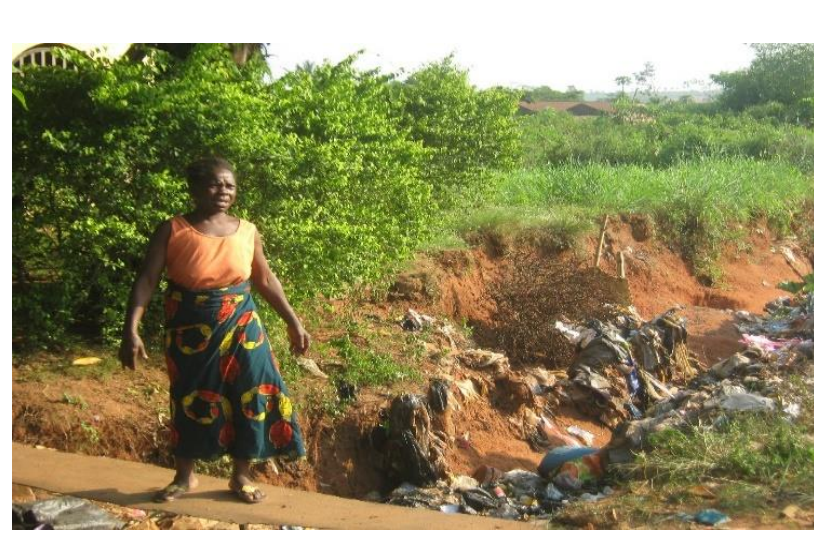

Plate 9: Road completely cut-off by erosion in Ogbeson quarter Benin City

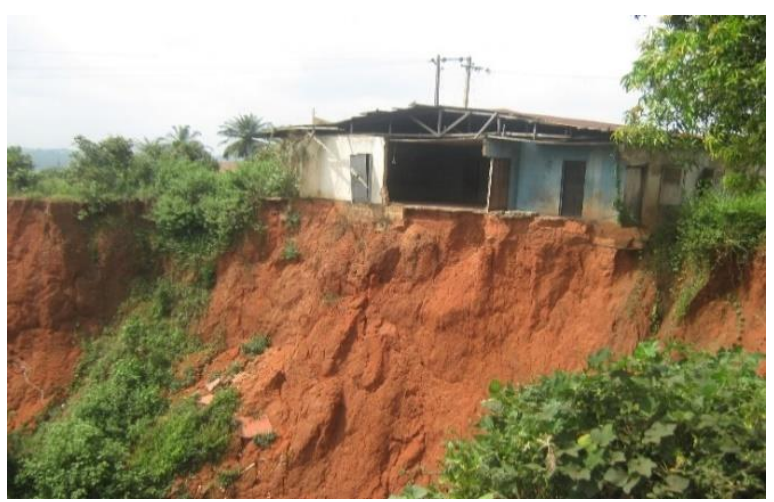

Plate 8: One of the residential buildings in Ogbeson quarters being threatened by Queen Ede erosion

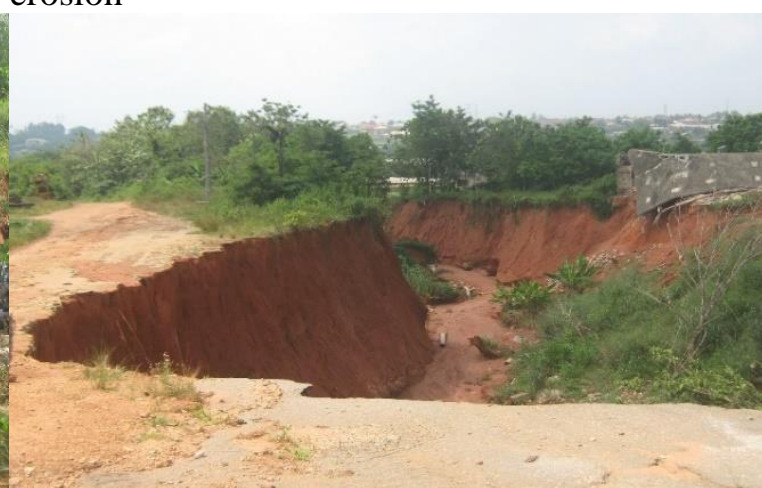

Plate 10: Erosion off major road in Ekehuan, Benin City

The rate of gully growth in Benin City is governed mostly by the geotechnical properties of the soils and the energy of the surface run-off. Gully growth rates and initiation have increased in recent years because of increased population pressure and resultant vegetation cover denudation. This in turn has created a state of social isolation for the communities located around the gully site. The agricultural activity within the affected region has reduced drastically and farm produce are left to rot during the wet season as a result of inaccessibility to farm lands.

Table 4 shows that over $30.5 \%$ of the respondents loose about N40,000-N100,000 to the 2012 flooding while $20.3 \%$ of the respondents loose N130,000-N150,000 to flooding. Also, $10.2 \%$ of the respondents declined this item. Common farm activities in the study area include fish farms, poultry, piggery and crop farming. These activities are carried out on both subsistent and commercial levels.

Table 4: Questionnaire result of amount lost due to farm submergence

\begin{tabular}{|l|l|l|}
\hline Amount lost due to farm submergence & No. of response & Valid Percent \\
\hline Below N30,000 & 19 & 16.1 \\
\hline N40,000-N100,000 & 36 & 30.5 \\
\hline N100,000-N130,000 & 15 & 12.7 \\
\hline N130,000-N150,000 & 24 & 20.3 \\
\hline N150,000 and above & 12 & 10.2 \\
\hline No response & 12 & 10.2 \\
\hline Total & 95 & 100.0 \\
\hline
\end{tabular}

The gender distribution of the respondents in Benin City is presented in Table 5. On the average majority of the respondents are male (79\%). This is expected in a patriarchal society where the head of the household is almost exclusively male. It can be seen that 92.6 per cent of the respondents said they were married (Table 5). This confirms the well-known fact that marriage is the preferred mode of adult life. We may also assume that on account of their maturity, the respondents fully understood our questions and the purpose of the survey and may have given valid answers. Benin City is inhabited by people with mixed occupational and economic backgrounds (Table 5). There are private and public servants, traders, small/subsistent farm holders, artisans and apprentices as well as housewives and 
unemployed persons. Many of these operate in the informal sector of the economy, a sector reputed to be outside the tax circle of government. Against the above background, it goes without saying that the affected persons and the general population could be classified as relatively poor. Most of the affected households keep some domestic animals and birds and also grow different types of crops, cassava, plantains and bananas, pawpaw, sugarcane, and sundry vegetable, which have been affected by flood and gully erosion. All domestic animals and birds as well as the various crops are used to supplement household food as well as for commercial purposes. Therefore agricultural activity within flooded and/or gully erosion affected areas is certainly on both subsistent and commercial scales.

Table 5: Respondents sex, marital status and livelihood

\begin{tabular}{|l|l|l|l|l|l|l|l|l|l|l|l|l|}
\hline & \multicolumn{3}{|c|}{ Sex } & \multicolumn{4}{c|}{ Marital status } & \multicolumn{4}{c|}{ Nature of livelihood in Benin City } \\
\hline & Male & Female & Sing & Marr & Div & W/W & Sep & PPS & SF & ART & TRD & APP \\
\hline Freq & 395 & 105 & 25 & 463 & 4 & 7 & 1 & 122 & 101 & 97 & 118 & 62 \\
\hline$\%$ & 79 & 21 & 5 & 92.6 & 8 & 1.4 & 0.2 & 24.4 & 20.2 & 19.4 & 23.6 & 12.4 \\
\hline
\end{tabular}

Sing: Singles; Marr: Married; Div: Divorced; W/W: Widow and Widower; Sep: Separated; PPS: Public/Private servants; SF: Subsistent Farmers; ART: Artisians: TRD: Traders; APP: Apprentices

In Table 6, over 70 per cent of the respondents claimed to be over 35 years. This clearly shows that our respondents fall within very active and virile age categories, the implication of which is that they belong to very important segment of the population in terms of economic production. In addition this age group is ideal for participation in any water resources development scheme.

Table 6: Mean age of respondents

\begin{tabular}{|l|c|c|c|c|}
\hline Age & No. of Respondents & Percent & Valid Percent & Cumulative Percent \\
\hline $17-25$ & 32 & 6.4 & 6.4 & 6.4 \\
\hline $26-35$ & 73 & 14.6 & 14.6 & 21.0 \\
\hline $36-45$ & 201 & 40.2 & 40.2 & 61.2 \\
\hline $46-55$ & 78 & 15.6 & 15.6 & 76.8 \\
\hline $56-65$ & 54 & 10.8 & 10.8 & 87.6 \\
\hline $66 \&$ above & 22 & 4.4 & 4.4 & 92.0 \\
\hline NA & 40 & 8.0 & 8.0 & 100.0 \\
\hline Total & 500 & 100.0 & 100.0 & \\
\hline
\end{tabular}

Edo State is one of the most educational States in Nigeria. The high educational standing of our field respondents is therefore not unexpected. A majority of 58.2 per cent of the respondents claimed to have one tertiary educational qualification or the other, that is, NCE (National Certificate in Education) or above (Table 7).

Table 7: Highest educational qualification of respondents

\begin{tabular}{|l|l|l|l|l|}
\hline Qualification & Distribution & Percent & Valid \% & Cumulative \% \\
\hline B.Sc.> & 92 & 18.4 & 18.4 & 18.4 \\
NCE & 199 & 39.8 & 39.8 & 58.2 \\
TC2 & 37 & 7.4 & 7.4 & 65.6 \\
SSCE & 101 & 20.2 & 20.2 & 85.8 \\
Others & 71 & 14.2 & 14.2 & 100.0 \\
Total & 500 & 100.0 & 100.0 & \\
\hline
\end{tabular}

Of the remainder, 14.2 per cent belong to the category of unclassified qualifications. This category is made up of respondents with some primary or high school education. Benin City has several higher educational institutions including the University of Benin, Benson Idahosa University and a few diploma awarding private institutions. High educational qualifications imply that respondents belong to the educational elite who are very conscious of the environment and may be easy to mobilize to engage in some form of action to ameliorate disasters such as flood and gully erosion in the area.

\subsection{Existing water resources development programmes in Benin City}

Generally some gullies are too severe to remedy, and will require huge engineering efforts (hydraulic regulation works); others can be tackled through a variety of best land management practices (agronomic) and low-cost approaches. The engineering measures includes the construction of 
engineering structures such as catch pits and soak-away pit, interceptor open drains, canals and underground pipes, with the objectives of preventing runoff from reaching the gullies and enhancing slope stability. The agronomic method provides the soil with physical protection against scour and in slowing down the velocity of flow by increasing the hydraulic resistance of the channel (Lal, 1998). The cover crops help in shading the land and reducing the impact of rain drop (erosivity), the roots help to hold the soil together. The upper parts of trees intercept precipitation and thereby reduce the kinetic energy of the raindrops. When the velocity of flow is sufficiently reduced, some of the sediment load will be deposited and this can lead to the desirable rigorous vegetation, siltation of the gully and densification of the soil until the gully is refilled with soil (Hudson, 1971). The application of any of the two mentioned methods requires a good knowledge of hydrometeorology, surface hydrology land use, catchment topography. Table 8, illustrates the causes of gully erosion in Benin City.

Table 8: Cause of gully erosion in Benin (Modified from EDO-NEWMAP, 2014)

Cause of gully erosion

Roads without proper drainage or catchments pits

Unsound cultivations leading to flooding

Indiscriminate channeling of flood water on sloped terrain, especially in loose soil structure area $* * *$

Intense rainfall (Benin city is in the Tropical Rainforest Zone)

Unregulated sand excavation

Poor drainage systems

*** The Benin formation comprise of mainly consolidated sand and sandy clays. The soils have low silt/clay content which decreases with depth. The soils are cohesionless, very permeable and have high infiltration rates, making control of gullies difficult after they have cut through the red soils at the surface. In addition, the rise in the water table due to heavy rain falls in the rainy season contributes to an increase in hydraulic head, high subterranean flow rate, and the enhancement of gully formation in the area (Nwankwoala and Ngah, 2014; Abam et al., 2016).

Regrettably, most of the hydraulic regulation projects have failed mainly due to poor feasibility study; inadequacy of hydrological data and even when such data is available, they are dis-jointed; noninvolvement of relevant stakeholder and the complete absence of community based groups during engineering construction works. For example Morgan (1986) showed that rainfall data collected for some Nigerian roads and observations on the performance of road culverts and roadside gutters during periods of heavy rainfall revealed major flaws in the design of highway drainage throughout in some parts of southern Nigeria (Morgan, 1986). As a result, gullies tend to form, where the concrete-lined drains and culverts are too small to accommodate peak surface runoff. Amangabara (2012) also showed that in most cases culverts are not terminated at base of- slope locations and are allowed to decay and become clogged with debris. The overflowing water erodes beneath the roadside gutter or culvert, which eventually falls away to provide a site of localized erosion. By the accumulation of larger quantities of water or by the gradual deepening, rills and erosion gullies of various sizes and forms come into being. Plates 11 and 12 illustrate some failed engineering interventions in the control of gully erosion in Benin City.

Meanwhile, public response to disasters including flooding in Nigeria commenced in 1976 with the creation of the National Emergency Relief Agency (NERA). It was renamed National Emergency Management Agency (NEMA) in 1999 to:

a. Formulate policy on all activities relating to disaster management in Nigeria and coordinate plans and programmes for efficient and effective response to disaster at the national level;

b. Coordinate and promote research activities relating to disaster management at National level;

c. Monitor the state of preparedness of all organizations or agencies which may contribute to disaster management in Nigeria;

d. Collate data from relevant agencies so as to enhance the forecasting, planning and field operation of disaster management;

e. Educate and inform the public on disaster prevention and control measures; and,

f. Coordinate and facilitate the provision of necessary resources for search and rescue and other types of disaster curtailment activities and distress call 


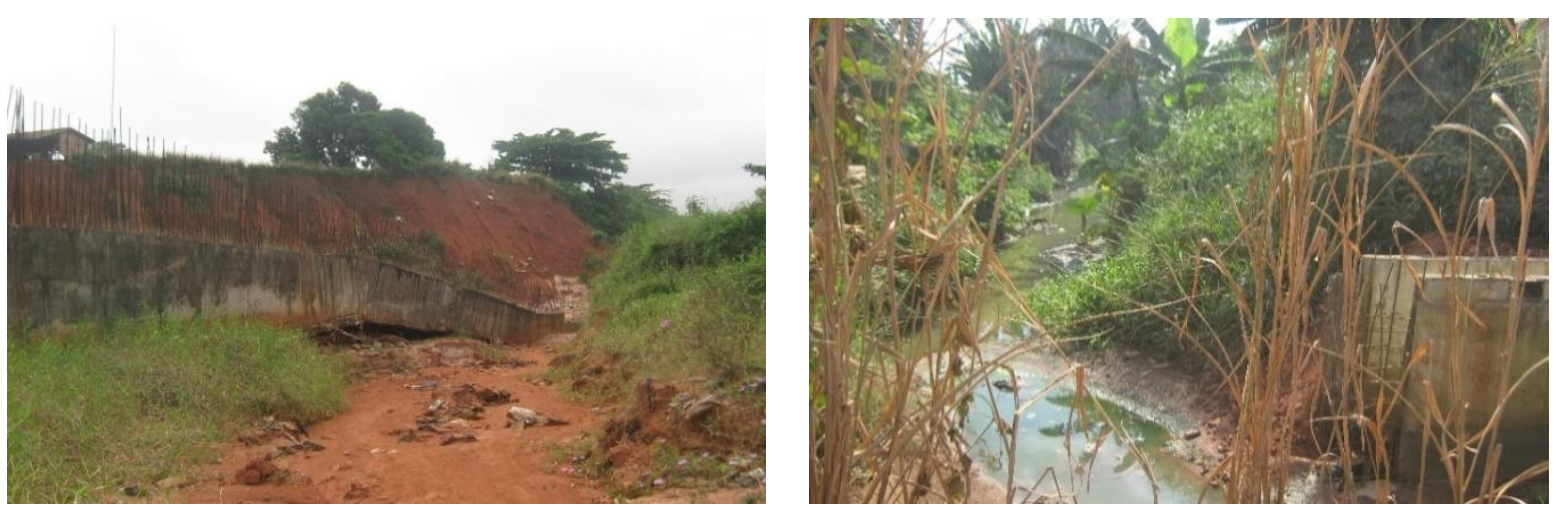

Plate 11: Failed Engineering Intervention at Queen Ede Gully erosion site/West Moat catchment in Benin City
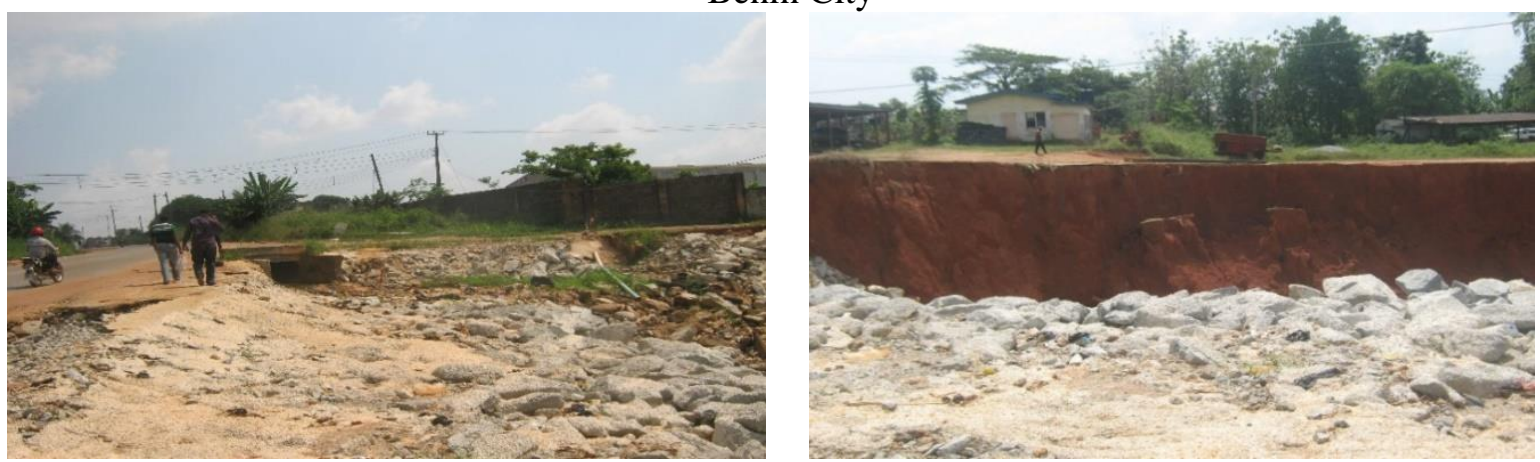

Plate 12: Failed Engineering Intervention at Ekehuan erosion site, in Benin City

NEMA is meant to be supported by its counterparts in each State of the Federation to manage ensuing disaster operations at respective local levels. Some NGOs are also visible in the country especially the Nigerian Red Cross Society (NRCS). In discharging its duties, NEMA adopts the disaster model of prepare, response, recover and mitigate (NEMA, 2011). By the Act establishing NEMA, all States in the Federation shall ensure the establishment of a body to be known as State Emergency Management Agency (SEMA) backed up by State Legislation. The legislation shall include provisions that will ensure that Local Governments in the State also establish authorities with similar functions. Community participation include to ensure commitment and preparedness of community members to disaster management; sensitize and build the capacity of communities that constitute disaster fronts in preparation for initial response to disaster threats; mobilize community resources and build community capacity and resilience to prepare for, respond to and mitigate the impact of disasters. Local Emergency Management Authority (LEMA) is to function with support from SEMA and NEMA (Figure 2).

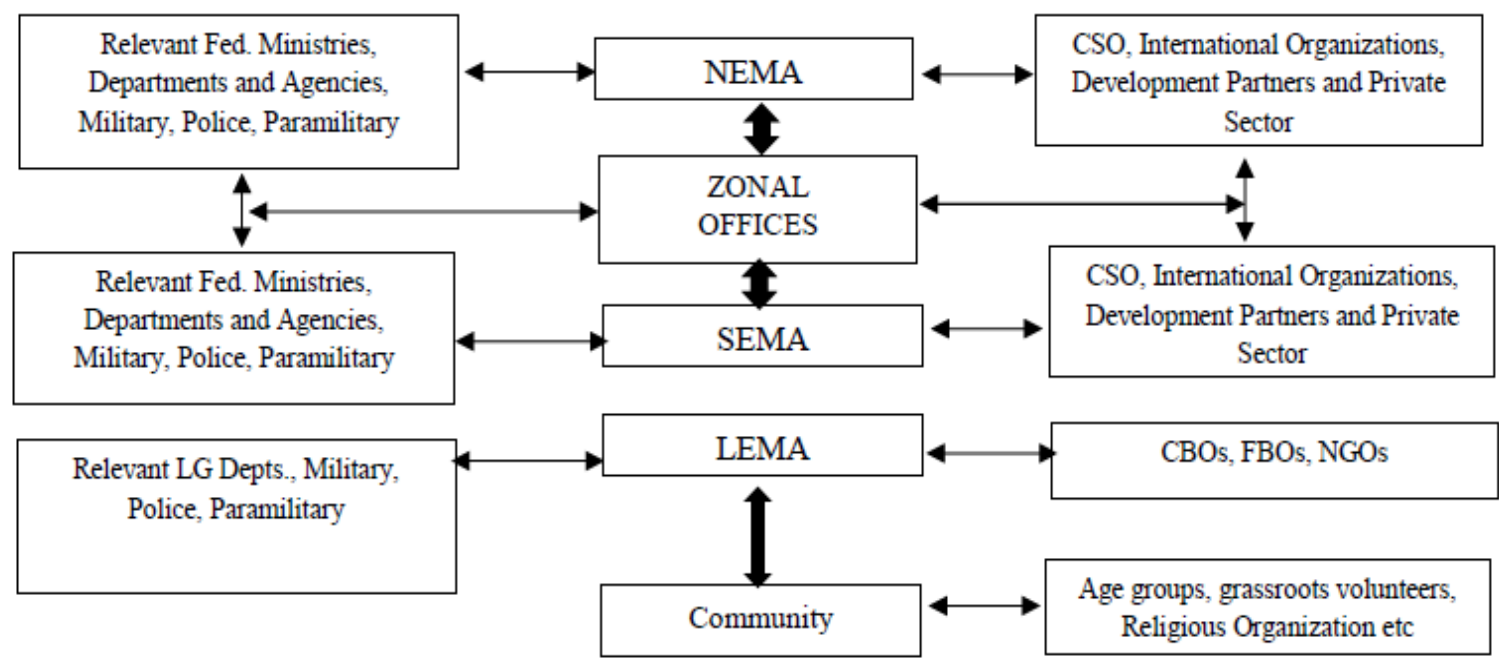

Figure 2: Horizontal and vertical coordination of disaster management in Nigeria Source: NEMA (2011) 
However, these efforts in respect of disaster management have been grossly inadequate. With respect to flood disaster, there is a complete absence of community participation in the national disaster response model in terms of preparation, recovery and mitigation phases. Instead the common practice is to involve community-based groups during response phase as vigilante groups, Faith-Based Organizations (FBOs), grass-root volunteers, i.e. that local based groups being considered as filling the 'gaps' in services not provided through formal government channels. According to NEMA, (2011); Olorunfemi and Adebimpe, (2008), NEMA's mandate has been hampered by inadequacies of strategy and resourcing; and other factors such as inadequate funding and equipment, weak executive capacity and lack of decentralization (Okoli, 2014). Another challenge to NEMA arises from the inability of the states and local Governments in Nigeria to buy into the national disaster management agenda.

The Federal Government had mandated the States to establish State Emergency Management Agencies (SEMAs). This is expected to be replicated at the Local Government level by creating Local Government Emergency Management Agencies (LEMAs). This directive has not been quite fruitful. While some States and Local Governments are yet to come up with their own SEMAs and LEMAs, those that have established theirs have not been making much significant impacts, which raise concerns concerning the strategic importance of such an endeavor (Adebimpe, 2011; Okoli, 2013). There is also the fear of non-state actors, taking the law into their own hands. This can be seen, first in the glaring disconnect between NEMA, SEMA, LEMA and community groups in the coordination of rescue and recovery operations and the fact that for the locals, there is no formal connections with NEMA and SEMA.

These limitations poses a serious challenge for disaster management in Nigeria and thus underlines the need to build local capacity for community population in terms of definition of structure and control framework (putting into consideration socio-economic), monitoring of changes, modes of reporting/documentation of management plans, funding mechanisms that include public and private sector participation. This is also in line with the standard set by the Hyogo Declaration (2005), which emphasizes on developing and strengthening institutions, mechanisms and capacities, particularly in communities, which can contribute systematically to improving resilience to hazards.

\subsection{Proposed hydrologically induced disaster management State-Non-state actors integrated model}

In this study we propose a model named Environmental Change Monitoring Committee (ECMC), which will be registered as a corporate organization to plan and monitor environmental changes relating to climate change, flood and gully erosion disasters and with the active involvement of NEMA, SEMA, LEMA and other related agencies and NGO, hence minimize the impacts of these hydrologically induced risks and disaster on the community (Figure 3).

Depending on the size of each Local Government Area, the proposed committee will comprise of 2550 members which are to nominated by community based groups (religious bodies, youth groups and committees of village meetings) and according to the procedure set by the constitution guiding each nominating group. In nominating the representatives of the committee, efforts must be taken to ensure equitable representation from different sections of society, in particular women and vulnerable groups. Minimum qualification for nomination is senior secondary school certificate (SSCE) and the fact the nominee is a member of the community. Since LEMA is already established by Act, the proposed committee should have an office space in the local government headquarter.

The Chairmanship and Vice Chairmanship of the committee will be headed by official of State Emergency Management Agency (SEMA) and Local Emergency Management Agency (LEMA) respectively, who will nominate two (2) secretaries from the members. There will be different subcommittees with various responsibilities. Each sub-committee is to be led by a sub-committee chairperson. The chairperson of each sub-committee will report to the central committee chair who will in turn report to advisory council for detailed review and action. The activities of committee, financial and other operations must be guided by a constitution to promote accountability and transparency. 


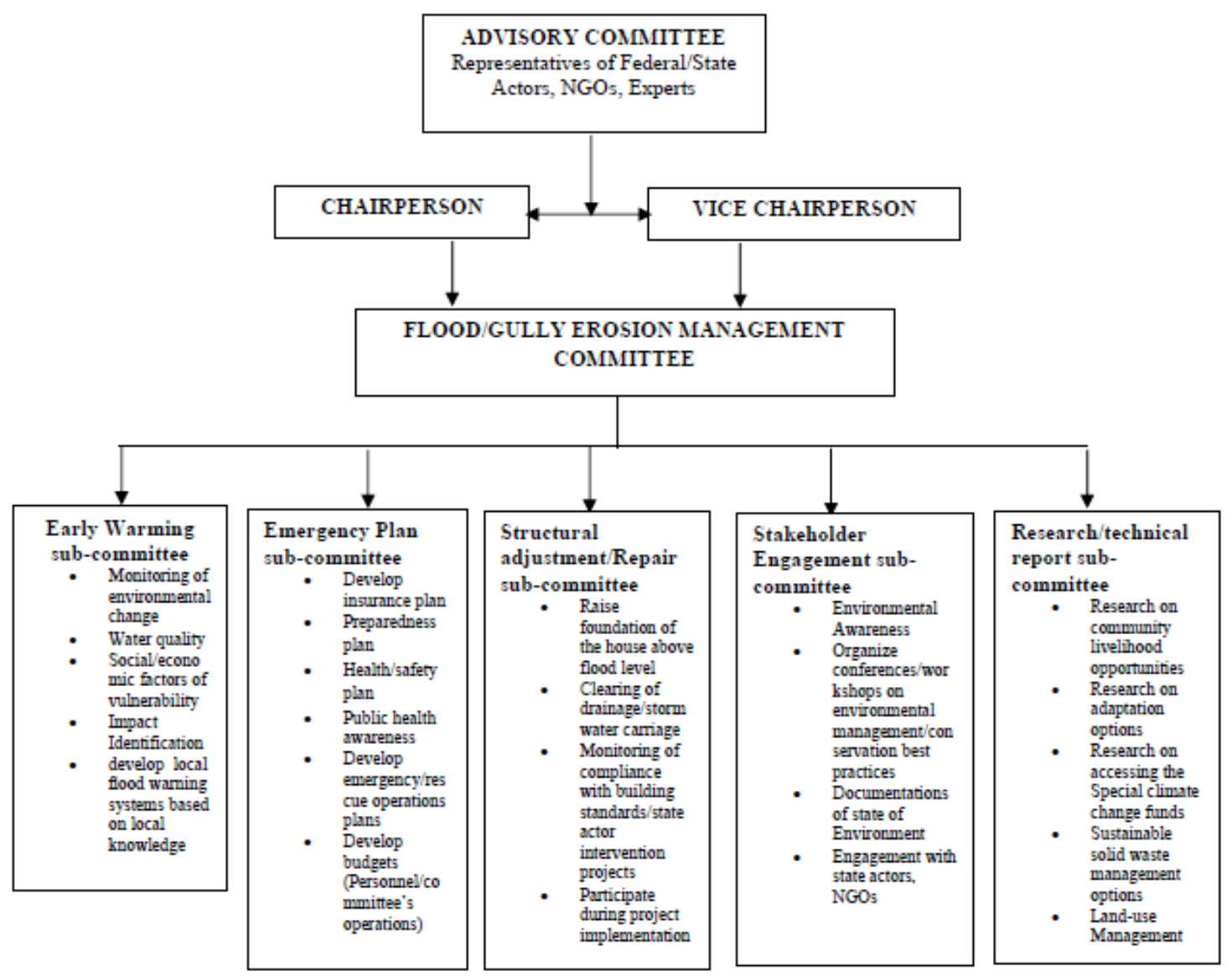

Figure 3: Structure and Responsibility of proposed State-Non-state actors Integrated Model Source: Authors Field Work (2018)

The committee is to be overseen by advisory committee consisting of representatives of NEMA, SEMA, LEMA and other federal and state agencies such as representative of ministries of environment, education, planning and physical infrastructure, water resources, lands and survey, climate change prediction centres, school teachers, local health workers, women affairs, research institutions, civil society groups, doctors and Nigerian Society of Engineers. Selection of members of the advisory council will be the prerogative of a joint committee of Federal/State Government. The roles of the advisory council will include; supervisory, funding, conflict resolutions, provision of institutional frameworks, implementation of action plans and oversee elections into committee executive positions. This advisory council will be headed by a representative of NEMA who will nominate a Vice and secretary from SEMA and Ministry of Environment. A comparison of all the FGDs data suggested the following factors of participation as follows (Table 8).

\subsection{Funding the Committee}

The committee's activities (vehicle, mobility, research, data collection, documentation) will require funding. Thus, the ECMC must be captured in the year-year appropriation bills of Federal and State Government. At least 5\% to $10 \%$ of annual budgets of target Ministries, Departments and Agencies, MDAS should be set aside for the operations of ECMC. At the moment, proposed potential funding agencies for this model include:

1) Federal, State and Local Governments of Nigeria, through NEMA, SEMA and LEMA

2) Federal Government of Nigeria, through National Ecological Fund

3) Federal Government of Nigeria through the preparation of the Nigeria Erosion and Watershed Management Project (NEWMAP)

4) Federal Government through Federal Ministry of Environment

5) State and Local Government through SEME

6) State Government through Ministries of Environment, State Rapid Response Teams 
7) International donors (some of the residents of the sampled arears are graduates and experienced researchers)

8) NGOs

9) Religious Bodies

10) Private sectors

Table 8: Proposed factors for sustainable community participation in Benin City

\begin{tabular}{|c|c|}
\hline Factor & Effects on Participation \\
\hline $\begin{array}{l}\text { Continuous community } \\
\text { engagement/participation with } \\
\text { NEMA/SEMA }\end{array}$ & $\begin{array}{l}\text { Creating a strong sense of belonging } \\
\text { Provision of supports and constant revenue to the monitoring/mobility } \\
\text { Enhance collaborations in the areas of early warming, emergency response, } \\
\text { resettlement or relocation of flood or gully erosion affected persons } \\
\text { Ensure sustainability of community participation in disaster management }\end{array}$ \\
\hline $\begin{array}{l}\text { Formation of flood/water quality monitoring } \\
\text { groups, solid waste management groups and } \\
\text { good land management units }\end{array}$ & $\begin{array}{l}\text { Facilitate operations and maintenance processes } \\
\text { Facilitate networking and collaboration among water users and/or with other } \\
\text { related water resources management agencies } \\
\text { Enlighten community members on the formation of community Interest } \\
\text { Groups (CIGS) }\end{array}$ \\
\hline $\begin{array}{l}\text { Networking and collaborations with NGOS, } \\
\text { International donors and state-actors }\end{array}$ & $\begin{array}{l}\text { Facilitate Sharing of new skills and training which help the various water } \\
\text { resources programmes (flood and gully erosion control/monitoring) meet } \\
\text { their goals and missions } \\
\text { Facilitate experts inputs/ development of change monitoring models } \\
\text { Enlighten communities on the criteria for accessing the Special Climate } \\
\text { Change Funds (SCCF) } \\
\text { Development of understanding, knowledge and skills to support partnership } \\
\text { working } \\
\text { Facilitate information sharing }\end{array}$ \\
\hline $\begin{array}{l}\text { Structural Coordination and organizational } \\
\text { management }\end{array}$ & $\begin{array}{l}\text { Facilitate monitoring and evaluation i.e. performance evaluation } \\
\text { Facilitate budget planning process and execution of water resources } \\
\text { development/management projects } \\
\text { Quick response/solution to early flood events and gully erosion formation } \\
\text { and post disaster intervention } \\
\text { Efficient, transparent and accountable revenue management } \\
\text { Reduces the stress of reaching state partnership }\end{array}$ \\
\hline Livelihood development & $\begin{array}{l}\text { Community empowerment/Community empowerment through additional } \\
\text { financial liberation through additional financial liberation } \\
\text { Enlighten community members on their roles in the delivery of livelihood } \\
\text { activities } \\
\text { Enlighten communities on eligible livelihood enhancement activities }\end{array}$ \\
\hline
\end{tabular}

Transparency and accountability of the funds used in the course of disaster management, monitoring and payment of members (payment structure is to determine by advisory council) is very important towards the sustainability of the committee. Therefore there must be six (6) months interval audit of the financial book of the committee by external certified auditors and the financial report presented to the advisory council, State/International donors, including stakeholders at community levels such as the Enogies (chiefs) and council of chiefs.

\subsection{Capacity building of committee members}

This involves capacity building of members in the form of training and re-training. Every subcommittee has different responsibilities in keeping with the mandate of the committee. More so every member in each subcommittee has different backgrounds, thus training and knowledge-sharing opportunities must be organized to empower these actors. Such training must cover skill development in the areas of early warning, preparedness, adaptation, emergency plan, data (rainfall) collection method/analysis and documentation, application for grants/ writing of research proposals to fund the activities of the committee, monitoring for environmental changes in including water quality monitoring, presentation of research findings. At least each member of the committee should be trained twice in a year.

\subsection{Conclusion}

This research serves as a pilot study for an integrated water resources management model. The success of the study will imply that similar committee should be created in each of the senatorial district in each state of the country. Edo state for example, where the study was undertaken similar 
committee can be created in the three senatorial zones whereas the advisory council can serve the three districts. The study shows potentials for sustainable disaster/environmental management, increase in income level of community members, informed policy on environmental management in the country, livelihood diversification, and improved economic development. Benin City is predisposed to flooding and gully erosion due to its geographical location (rainfall amount, soil type and increasing pressure on natural resources arising from population expansion). The trend is not expected to change; however, by involving community members in a sustainable way towards the management of these problems as against the top-down approach, is expected to be economical as well as holds the potentials for a lasting solution to minimize conflict of interest and also give the people a sense of ownership. The researchers are confident in the effectiveness of this model as age brackets, educational qualification and level of location knowledge of local environment of the respondents were considered.

\section{References}

Abam, T. K. S., Akpe, A. C. and Oba, T. (2016). Topography and Particle Size Gradation Characterization of the Benin Formation in the Lower Niger Delta, Nigeria. Journal of Earth Sciences and Geotechnical Engineering, 6(2), pp. 63-71.

Adebimpe, R. U. (2011). Climate change related disasters and vulnerability: An appraisal of the Nigerian policy environment. Environmental Research Journal, 5(3), pp.97-103.

Adejuwon, G. A. and Aina, W. A. (2014). Emergency Preparedness and Response to Ibadan Flood Disaster 2011: Implications for Wellbeing. Mediterranean Journal of Social Sciences, 5(8), pp. 500511

Akujobi, J. (2013). National disaster management in Nigeria. Disaster risk management in Nigeria in Nigerian rural and urban settlements. Published by Nigerian Institute of Town Planners (NITP) and Town Planners Registration Council of Nigeria (TOPREC) pp.73-87.

Akuto, G. W. (2017). Challenges of Internally Displaced Persons (IDPs) in Nigeria: Implications for Counselling and the Role of Key Stakeholders. International Journal of Innovative Psychology \& Social Development, 5(2), pp. 21-27.

Alaci, D. S. A., Adaaku, E. M. and Jiya, S. N. (2017). Disaster Risk Reduction Framework as Paneacea for Coping with Flood Events in Nigeria. Dutse Journal of Pure and Applied Sciences 3(1), pp. 58-71

Al-Hassan, I. and Momoh, N. (2006). Impact of Gully Erosion on Built-up Areas of Auchi. Paper presented at Chemtech Conference, Edo State Chapter on the 27th July.

Aliyu, H. I., Nura, A. Y. and Abiodun, O. A. (2017). Assessing the Socio-economic Impact of Gully Erosion in Chikun Local Government Area, Kaduna State, Nigeria. Science World Journal, 12(1), pp. $42-47$

Amangabara, G. T. (2012). Analysis of Selected Failed Gully Erosion Control Works in Imo State. Hydrology for Disaster Management. Special Publication of the Nigerian Association of Hydrological Sciences, pp. 279-287

Anderson, M. G. and Holcombe, E. (2013). Community-based landslide risk reduction: Managing disasters in small steps. Washington, DC: World Bank.

Babatunde, J. A., Ayobami, T. S. and Mark, T. (2011). Developing Climate Change Scenarios, Biophysical Impacts and Adaptation Strategies in Nigeria. A final report submitted to Nigerian Environmental Study/Action Team (NEST) as part of the Building Nigeria Response to Climate Change (BNRCC) Project. 
Essoh, G. E. and Abutu P. O. (2018). Managing National Emergency in Nigeria: Prospects and Challenges. Journal of Good Governance and Sustainable Development in Africa (JGGSDA), 4(1). Available online at http://www.rcmss.com/index.php/ijpamr; www.academix.ng

Hudson, N. (1971). Soil Conservation. B.T. Batsford Limited, London. 320pp

Hughes, A. O., Prosser, I. P., Stevenson, J., Scott, A., Lu, H., Gallant, J., et al. (2001). Gully erosion mapping for the National Land Water Resources Audit. Technical Report 26/10, CSRO Land and Water, Cambera, Australia.

Hunt, D. T. E. and Wilson, A. L. (1986). The chemical Analysis of water (General principle and Technologies). 2nd edition the Royal society of chemistry, London. 683pp

Hyogo Framework for Action 2005-2015 (2015). Building the Resilience of Nations and Communities to Disasters. Mid-Term Review 2010-2011.

Ibitoye, M. O. (2006). An assessment of accelerated erosion in Irele LGA, Ondo State, Nigeria, Unpublished M.Sc thesis, Institute of ecology and Environmental Studies, Obafemi Awolowo University, 102pp.

Iguniwari, T. E. (2018). Evaluation of Hydrological Data Collection Challenges and Flood Estimation Uncertainties in Nigeria. Environment and Natural Resources Research, 8(2), pp. 44-54.

Jeje, L. K. (2005). Urbanization and Accelerated Erosion: The case of Effon-Alaye in Southwestern Nigeria. Seminar paper, Department of Geography, Obafemi Awolowo University, Ile-Ife, Nigeria

Lal, R. (1998). Soil Erosion Impact on Agronomic Productivity and Environment Quality. Critical Reviews in Plant Sciences. 17(4), pp. 319-464.

Marfai, M. A., King, L., Sartohadi, J., Sudrajat, S., Budiani, S. R., and Yulianto, F. (2008). The impact of tidal flooding on a coastal community in semarang, indonesia. The Environmentalist, 28(3), pp. 237-248.

Matthew, O. I. and Suleiman, A. (2012). Indigenous Approach to Soil Erosion control in the Southwest Nigeria; Geomatt Associates and Environmental Services and Department of Remote Sensing and GIS, TS08F - Planning, Environment and Tourism, 6059.

Morgan, R. P. C. (1986). Soil erosion and conservation. Essex: Longman Group. Inglaterra, 298

Murck, B. W., Skinner, B. J. and Porter, S. C. (1996). Environmental Geology. New York.

National Population Commission (2006). Federal Republic of Nigeria, 2006, Population and Housing Census, Vol (III) National Population Commission Abuja, Nigeria April, 2010

NEMA (2011). 2010 Annual Report. National Emergency Management Agency, Abuja- Nigeria.

NEMA (2012). 2011 Annual Report. National Emergency Management Agency, Abuja- Nigeria

Edo-NEWMAP (2014). Edo State World Bank Assisted Nigeria Erosion \& Watershed Management Project: Resettlement Action Plan (RAP) Final Draft For Ekehuan Erosion Gully Site in Benin City, Edo State, Edo State Ministry of Environment and Public Utilities

Nwankwoala, H. O. and Ngah, S. A. (2014). Groundwater resources of the Niger Delta: Quality implications and management considerations. International Journal of Water Resources and Environmental Engineering. 6(5), pp. 155-163.

Nwilo, P. C., Olayinka, D.N., Uwadiegwu, I. and Adzandeh, A. E. (2011). An Assessment and Mapping of Gully Erosion Hazards in Abia State: A GIS Approach. Journal of Sustainable Development, 4(5), pp. 196-211. 
Obiadi, I. I., Nwosu, C. M., Ajaegwu, N. E., Anakwuba, E. K., Onuigbo, N. E., Akpunonu, E. O., et al. (2011). Gully Erosion in Anambra State, South East Nigeria: Issues and Solution. International Journal of Environmental Sciences, 2(2), pp. 95-804

Ogboi, K. C. (2013). Disaster risk management and adaptation strategies: Challenges and opportunities for physical planning education and practices in Nigeria. Disaster risk management in Nigerian rural and urban settlements. Nigerian Institute of Town Planners (NITP) and Town Planners Registration Council of Nigeria (TOPREC), pp. 93-123.

Ojigi, M. L., Abdulkadir, F. I. and Aderoju, M. O. (2013). Geospatial Mapping and Analysis of the 2012 Flood Disaster in Central Parts of Nigeria 8th National GIS Symposium. Dammam, Saudi Arabia, April 15-17

Okoli, A. C. (2013). Emergency management and Nigeria's national security: examining NEMA's role in oil pipeline disasters in South-eastern Nigeria. PhD Dissertation submitted to Department of Political Science and Defence Studies, Nigerian Defence Academy (NDA), Kaduna.

Okoli, A. C. (2014). Disaster Management and National Security in Nigeria: The Nexus and the Disconnect. International Journal of Liberal Arts and Social Science, 2(1), pp. 21-59.

Olayinka, D. N., Nwilo, P. C., and Emmanuel, A. (2013). From Catchment to Reach: Predictive Modelling of Floods in Nigeria.

Olorunfemi, F. B. and Adebimpe, R.U. (2008). Sustainable disaster risk reduction in Nigeria: Lesson for developing countries. African Research Review, 2(2), pp.187- 217.

Rowlands, A. (2013). Disaster Recovery Management in Australia and the Contribution of Social Work. Journal of Social Work in Disability \& Rehabilitation, 12, pp. 19-38.

Slotterback, C. and Crosby, B. (2012), Designing Public Participation Processes. Public Administration Review, 73(1), pp. 23-34.

Ubachukwu, N. N. and Emeribe, C. N. (2017). The 2012 Flooding in Selected Parts of Isoko South, Delta State: Assessment of Socio-Economic Impacts. Mediterranean Journal of Social Sciences 8(1), pp. 353-358.

Unicef (2014) Unicef Nigeria Sahel crisis situation report, pp.1-2.

Wall, G., Baldwin, C. S. and Shelton, I. J. (2003). Soil Erosion - Causes and Effects Ontario Ministry of Agricultural and Food, Ontario, Canada. 